\title{
O DANÇAR DO GRUPO ARARUNA: COMPONDO UMA ESTÉTICA DO CORPO NA CULTURA POTIGUAR
}

E. J. Santos*; R. M. N. Medeiros
Universidade Federal do Rio Grande do Norte - UFRN
emanuellejds@hotmail.com*
Artigo submetido em novembro/2014 e aceito em abril/2016
DOI: $10.15628 /$ holos.2016.2559

\section{RESUMO}

O estudo tem a intenção de elaborar uma atmosfera estética do corpo e da cultura para a Educação Física tendo como principais componentes de reflexão as narrativas musicais do Grupo Araruna e suas simbologias. Situamos esse Grupo de danças tradicionais no mundo vivido fenomenológico de Merleau-Ponty, com o objetivo de compreendê-lo através da interpretação e imputação de sentidos contidos no universo estético das canções denominadas Araruna, Camaleão, Besouro, Mulher Rendeira e Mazurca. Essa musicalidade se configura como emblemático exemplar da tradição, pois mistura significações das culturas europeia e potiguar, fazendo com que o corpo habite, em sua memória, as simbologias da sexualidade, da natureza, do masculino e feminino, do sagrado e profano, do popular e erudito. Perspectivamos mobilizar outras reflexões que considerem a voz dos brincantes, o espaço, o tempo, a gestualidade da dança, o figurino, a maquiagem, entre outros componentes cênicos do Araruna, estando em sintonia com uma visão mais contemporânea da tradição.

PALAVRAS-CHAVE: Estética, dança, corpo, cultura.

\section{THE DANCE OF GROUP ARARUNA: COMPOSING AN AESTHETIC OF THE BODY IN POTIGUAR CULTURE}

\begin{abstract}
The study intends to develop an aesthetic atmosphere of body and culture for Physical Education whose main components of reflection on musical narratives of the Group Araruna and its simbologies. We situate this Group of traditional dances in the lived phenomenological universe of Merleau-Ponty, with the aim of figure out through interpretation and attribution of senses restrained in the aesthetic universe of songs called Araruna, Camaleão, Besouro, Mulher Rendeira e Mazurca. That musicality is configured as emblematic
\end{abstract}

example of tradition, cause it mixes meanings of European and Potiguar ("Potiguar" means that comes from Rio Grande do Norte) culture, making that the body put in his memory, the symbologies of sexuality, nature, male and female, sacred and profane, the popular and erudite. With the prospect of mobilizing other reflections that consider the voice of the players, the space around, the time, the gestures of the dance, the costumes, makeup, among other scenic of Araruna, being in tune with a more contemporary view of tradition.

KEYWORDS: Aesthetics, dance, body, culture. 


\section{INTRODUÇÃO}

O Grupo "Araruna: Associação de Danças Antigas e Semi-Desaparecidas" foi criado pelo Mestre Cornélio Campina da Silva (1908-2008) e fundado nos anos de 1950, sob o apoio de figuras importantes, como Câmara Cascudo, Djalma Maranhão e Veríssimo de Melo. O Araruna apresenta, em sua estética, danças antigas que já estiveram nos salões mais luxuosos da aristocracia natalense. Essas danças narram sobre a cultura norte-rio-grandense, expressando nitidamente influências de festas antigas da cultura europeia, bem como outros sentidos culturais e simbologias que vão muito além do pouco que já foi escrito e pensado sobre esse fenômeno.

Partindo dessa visão, o presente artigo se configura em uma reflexão sobre as relações simbólicas do corpo e a dança na Educação Física. O texto realiza uma análise estética em torno dos temas do corpo, da dança e da cultura, partindo da seguinte questão: em que medida as canções das danças do Grupo Araruna desvelam uma estética do corpo na cultura potiguar? Imersos nessa inquietação, apresentamos como objetivo de elaborar uma atmosfera estética do corpo e da cultura para a Educação Física através da reflexão interpretativa das palavras, narrativas e simbologias contidas nas canções do Araruna. Essa lacuna vem da identificação de que existem poucos estudos que tematizam o Grupo, ou mesmo não relacionam as simbologias da dança e da estética do corpo1.

A intenção de alargar o horizonte de percepção do fenômeno em estudo consiste em se atentar a sensibilidade, a gestualidade e a sonoridade do corpo que, ao dançar uma música também canta e encanta, pois desnuda a beleza expressiva da cultura potiguar compondo uma orquestra de excitações rítmicas, vibrações, pulsações e sensações regidas pelos versos, que fluem na melodia das palavras movidas pela musicalidade corporal no instante presente em que dança.

A dança imprime um grande potencial expressivo da sensibilidade, pois a beleza de suas ações mobiliza os códigos gestuais, capacitando a comunicação e percepção mais sensível de nossa cultura. Haja vista que a suavidade dos corpos em movimento, o ritmo calmo e contagiante da musicalidade das canções, fazem os corpos vibrarem, nos envolvem e também animam o olhar de quem aprecia tão bela apresentação desses brincantes.

A ação de dançar significa celebrar a vida por meio do movimento humano à procura da beleza da existência, realizando uma reflexão corporal na qual permite o meu olhar ir ao encontro com os símbolos, o imaginário, a história e a sexualidade, para comunicar minha relação com a natureza, a cultura e a história, expressando meus laços afetivos com os outros e com o mundo (NÓBREGA, 2008b). Habitar essas danças é uma atitude de povoar as significações tradicionais da cultura norte-rio-grandense, fazendo todo nosso corpo se engajar em um fenômeno efêmero, íntimo e mais físico com a cultura, pois potencializa nossa sensibilidade no processo de elaboração estética da prosa do movimento humano, reunindo recursos simbólicos para alçar outros voos do pensamento e da própria existência. Assim, percebemos que o ato de dançar sugere ao corpo um

\footnotetext{
${ }^{1}$ Os trabalhos que mais se aproximam dessa reflexão são o de Monteiro (2007) e Martins (2013). Respectivamente, o primeiro estudo faz uma análise da conformação estética, em Educação Física, voltada à estruturação didática das danças; já o segundo investiga, pelos conhecimentos da geografia, o espaço das práticas culturais construídas e vividas pelo Grupo Araruna. Cada uma dessas pesquisas, dentro de suas especificidades, tem sua relevância, entretanto, ainda não foi realizado um estudo que pretenda refletir analisar a estética do corpo e as simbologias das canções do Araruna.
} 
alargamento de sua condição humana, visto que ele incorpora várias funções expressivas que trazem uma tradição, uma memória, uma identidade, uma maneira de ser, sentir, agir e conviver.

Dançar é um ato natural e, ao mesmo tempo, social, que não existe fora de um corpo humano, pois essa ação transcreve marcas da cultura e da história, aguçando a memória e a imaginação humana por meio de seus códigos próprios, sua textualidade e estética singular traduzem também um intenso amor à dança (NÓBREGA, 2008a). Inflamados por esse entendimento, refletir sobre a manifestação existencial da estética corpórea, através das simbologias das canções do Araruna, é se desvencilhar de uma visão nostálgica, purista ou mesmo fantasiosa da dança, que, por vezes, reforça a problemática de um entendimento empobrecido da cultura e do próprio humano, alargando fraturas ideológicas e epistemológicas entre razão e emoção, corpo e mente, sagrado e profano, erudito e popular. Logo, o encantamento com esse Grupo surgiu em apreciações de apresentações do Araruna na cidade do Natal/RN, juntamente com os estudos acadêmicos sobre dança e cultura que também balizam as ideias deste texto.

\section{REVISÃO BIBLIOGRÁFICA}

O estudo aborda a estética do corpo e da cultura potiguar com fins de desdobramentos reflexivos para a Educação Física, tendo como lócus de investigação a expressividade simbólica do Grupo Araruna, tendo como principais componentes de reflexão as narrativas musicais e suas simbologias. Nesse sentido, reconhecemos que as danças tradicionais apresentam um rico conhecimento da nossa condição de sermos brasileiros, integrantes de uma cultura híbrida, que é profundamente marcada por múltiplos saberes simbólico-culturais que extrapolam os sentidos de uma visão linear e, ao mesmo tempo, pode ser transpassada por esta através de paradoxos existenciais que compõem fios de sentidos para a composição de uma estética do corpo e da Educação Física. Essas danças se revelam como conhecimentos culturais, sensíveis, integradores e intensos, que são transmitidos no seio familiar e recriados de geração em geração, constituindose, dessa maneira, em verdadeiras "escolas da vida", pois dão muitas lições para o viver e conviver. Essas danças apresentam uma estética, uma simbologia e um contexto específicos, caracterizandose "pelo forte sentido de agregação de seus membros na busca da vivência estética, que media todo o ritual de preparação das danças a serem apresentadas e compartilhadas por outros membros da sociedade" (PORPINO, 2006, p.114).

Olhar é interpretar, interrogar, pesquisar e surpreender, dando sentido ao fenômeno cultural do Araruna para além do que já foi visto e dito. Assim, pesquisar é semelhante ao movimento do olhar, fazendo o corpo "ir mais longe", não se reduzindo a um simples caminhar, mas sim configurando o exercício reflexivo na busca incessante pela restituição do sentido das coisas, "como se cada passo dado exigisse e tornasse possível um outro passo, como se cada expressão bem-sucedida prescrevesse ao autônomo espiritual uma outra tarefa ou, ainda, fundasse uma instituição cuja eficácia nunca terá terminado de experimentar" (MERLEAU-PONTY, 2004, p.83).

Para a fenomenologia, o ato de olhar requer um aprendizado, uma mobilização, uma experiência sensível e também uma certa disponibilidade do corpo se mover em busca daquilo que o seu olho foi sensibilizado e impactado pelo mundo visível. Dessa maneira, o corpo se confunde com o mundo do qual contempla, confundindo-se com ele, torna-se um mundo em si. Em outras 
palavras, "o espírito do mundo somos nós, a partir do momento em que sabemos mover-nos, a partir do momento em que sabemos olhar" (MERLEAU-PONTY, 2004, p.98).

Em "O olho e o espírito", Merleau-Ponty (2004) realiza uma crítica à ciência positivista e às reflexões racionalistas, que desconsideram o solo fértil da subjetividade e da historicidade humana, nos convidando a um exercício de pensamento filosófico que abarque o espanto, o paradoxo, o diverso, a interrogação infinita, a imprevisibilidade do fenômeno e o território da experiência existencial da vida, em suma, uma visão mais ampla desse "corpo atual que eu chamo de meu, a sentinela que se posta silenciosamente sob minhas palavras e meus atos" (Ibidem, p.14).

Assim como o pintor oferece seu corpo e sua visão, pondo-se a pintar e transformar o mundo em pintura, o brincante que dança também doa toda sua potência muscular para celebrar o enigma de uma corporeidade tecida no mundo da dança. Essa filosofia do sensível se manifesta por meio de entrelaçamento febril entre invisível e visível, tocante e tocado, essência e existência; todos esses pontos são profundamente marcados pelo encontro do olhar com a significação, processo em que não há separação entre a expressão e o expresso, o ato e a significação (NÓBREGA, 2010).

O corpo é compreendido como sinônimo do próprio ser humano, isto é, o próprio eu, é o eu-corpo que vive, existe, se movimenta, dança, embelezando o mundo e sua existência. Na visão de Merleau-Ponty (1999), o corpo não se reduz a um amontoado de músculos e ossos, mas ele é expressão cultural e subjetiva da vida humana, sendo comparado primeiramente a uma obra de arte, revelando-se como um nó de significações vividas e sentidas na vibração subjetiva e objetiva, isto é, no entrelaçamento existencial da vida humana, admitindo a condição quiasmática ${ }^{2}$ de sujeito/objeto que se revela em um episódio único, nossa própria corporeidade.

Os corpos são atravessados pelas emoções do ato de dançar, juntamente pelos aspectos simbólicos, artísticos, sociais e históricos da cultura, trazendo valiosas contribuições para a composição de uma estética para a dança e a Educação Física. Dessa forma, a estética se entrelaça a motricidade do corpo, as funções simbólicas e a sensibilidade humana, convidando à contemplação do belo, convocando-o a elaborar novas coreografias do (con)viver no mundo. Logo, as intervenções sociais e a própria produção de conhecimento científico da Educação Física necessita levar em conta a possibilidade de compor uma estética que amplie "[...] a operação expressiva do corpo e da percepção, afinando os sentidos, aguçando a sensibilidade, elaborando a linguagem, a expressão e a comunicação" (NÓBREGA, 2010, p.94).

Por essa lógica, a estética é percebida como uma experiência sensível que provoca beleza capaz de permitir um entrelaçamento entre a obra e o sujeito que a percebe. A estética não se reduz a uma visão categórica ou uma ideia estanque, mas sim propicia a vivência do sensível, constituindo-se como a verdade de um sentimento humano sobre a arte de viver e criar novos horizontes existenciais (PORPINO, 2006).

2 O termo quiasma se mostra como um fenômeno que entrelaça o eu-corpo com o mundo, revelando uma expressão de atos sensíveis desse mesmo mundo, não se reduzindo a uma simples antítese do para si e do para outro, mas sim realizando uma unidade existencial entre o meu mundo e o mundo do outro (MERLEAU-PONTY, 1971). 
A estética que se refere a um conhecimento sensível, inevitavelmente ligado à arte, ao belo, à sensibilidade e ao prazer. Contudo, tal ideia não está confinada à dimensão artística e subjetiva do ser humano ou somente a seus saberes cotidianos, pois a estética também se refere às outras racionalidades e aos conhecimentos científicos, inclusive à área da Educação Física. Acolhendo essa visão, refletimos sobre a maneira como a estética dos corpos é transpassada pelas danças tradicionais, historicidades e subjetividades dos corpos brincantes. As significações estéticas estão entrelaçadas à cultura, à natureza, às músicas, aos corpos e às gestualidades coreográficas, em suma, a toda expressividade existencial do Grupo em si.

\section{ABORDAGEM METODOLÓGICA}

A pesquisa se caracteriza pela sua natureza qualitativa, tendo como metodologia a fenomenologia de Maurice Merleau-Ponty para a feitura de uma descrição minuciosa dos dados do nosso objeto. Essa metodologia, segundo Nóbrega (2010, p.36), nos leva aos "caminhos da reflexão epistemológica da corporeidade em diálogo com outros desdobramentos das ciências", no nosso caso, a Arte e a Filosofia para pensar a Educação Física.

O método fenomenológico é, antes de tudo, a atitude de envolvimento com o mundo da experiência vivida, com o intuito de compreendê-la. Essa posição não é uma representação mental do mundo, mas envolvimento que permite a experiência, a reflexão, a interpretação, a imputação e a compreensão de sentidos (NÓBREGA, 2010, p.38).

Antes da teorização, a tarefa consiste em buscar por palavras e narrativas gestuais do Araruna, reconhecendo seu mundo vivido e simbólico por meio do material do SESC/RN (COSTA, $2008)^{3}$, estudando a maneira como o Grupo se singulariza na condição de partícipe da cultura potiguar pelo diálogo com alguns autores como Chevalier, Eliade e Merleau-Ponty. Essa reflexão está ancorada no detalhamento de alguns sentidos do corpo e simbologias expressas nas narrativas das canções de cinco danças: Araruna, Besouro, Camaleão, Mulher Rendeira e Mazurca. O contato com esse universo permitirá um entrelaçamento entre o universo da cultura, do corpo e da estética.

Após o exercício de circunscrever nosso campo fenomenal, faremos uma breve contextualização das nuances que caracterizam o Araruna, bem como a estética do corpo e as peculiaridades narrativas das referidas canções, criando novas interrogações das entrelinhas, encontrando os fios de significações e intencionalidade, através do encontro e das mesclas intersubjetivas, que arquitetam os sentidos existentes no Grupo em si, potencializando as reflexões da Educação Física, do corpo e da cultura, nos levando ao caminho de uma lógica interpretativa mais sensível do objeto.

Feito isso, a redução fenomenológica do fenômeno estudado se atentará na organização, sintetização e interpretação do objeto através da atitude de ler e ouvir as canções, apreciando as palavras e narrativas das danças registradas no referido material do SESC/RN. Essa delimitação e análise reflexiva desse material consistirão em uma terceira etapa investigativa: a redução

\footnotetext{
${ }^{3}$ A obra é composta por um livro, com 151 páginas, e um vídeo, de duração de 10 minutos e 55 segundos, da qual tematiza peculiaridades do Grupo "Araruna: sociedade de danças antigas e semi-desaparecidas", tendo o interesse de homenagear o mestre Cornélio, criador do Grupo, reunindo registros valiosos sobre suas danças e respectivas canções.
} 
fenomenológica. Essa atitude revela-se como ato de admiração diante do mundo da tradição, pela necessidade de se misturar, se engajar na experiência vivida do corpo que dança e comunica a cultura potiguar, buscando compreender esse fenômeno na contemporaneidade (NÓBREGA, 2010). Tal compreensão é uma atitude de se distanciar e dar um novo significado ao Araruna.

Aliada a essa ideia, Medeiros (2010, p.22) explicita que a redução fenomenológica se configura no exercício de interpretar e reinterpretar o fenômeno estudado, de maneira a traçar "um caminho para a busca de novos sentidos e significados relativos ao corpo, à dança, à educação e à cultura". Isso tudo de modo que é impossível tê-lo por completo, sempre algo escapará a nossa compreensão. Por isso, é fundamental interrogar, suspender, criar e descobrir infinitos sentidos, delimitando-o ao que é visto, percebido e interpretado por quem pesquisa.

A redução é uma análise intencional, perceptiva, sensível, na qual sempre haverá abertura para o inédito e instigante ofício de dar sentido, arrumar ideias, questionar o escrito, ponderar, arriscar e articular algumas partes para tracejar percursos interpretativos das palavras e narrativas das referidas danças, migrando para outros mundos. Ou mesmo, como uma bordadeira, engajada na elaboração de sua peça artesanal, dispõe de todo o seu tempo no esforço de entrelaçar fios das simbologias existentes nas canções, desfazê-los e refazê-los, construindo uma bela obra de arte.

Essa imagem se aproxima do processo de reflexão na fenomenologia, pois Merleau-Ponty (1999, p.10) afirma que:

\footnotetext{
A reflexão não se retira do mundo em direção à unidade da consciência enquanto fundamento do mundo; ela toma distância para ver brotar as transcendências, ela distende os fios intencionais que nos ligam ao mundo para fazê-los aparecer, ela só é consciência do mundo porque o revela como estranho e paradoxal.
}

Distender os fios intencionais, retomar os sentidos originais das canções do Araruna, permite a tecitura de um bordado, que, a todo tempo, é feito e desfeito por meio de um movimento de junção e separação das linhas de sentidos constitutivos do objeto investigado. Esse exercício se dará pela suspensão de ideias, espanto com as novidades de interpretação do fenômeno Araruna, bem como da elaboração dos registros, descrições e interpretações sobre atmosfera estética do corpo que dança, canta e faz cultura para construir outros itinerários do sensível para a Educação Física.

\section{A MUSICALIDADE DO ARARUNA COMO EXEMPLAR ESTÉTICO}

A musicalidade do Grupo Araruna está expressa no timbre e na melodia de suas narrativas, no ritmo suave das palavras e na riqueza de suas simbologias presentes nas letras de suas canções, que evidenciam a beleza de nossa cultura potiguar. Segundo Pavis (2003, p. 130), a música "é como uma luz da alma que desperta em nós" uma estética da tradição que se caracteriza pela intensidade da emoção, pela fluência do gesto corporal e pela acentuação rítmica de cada nota no tempo e espaço da cena. Ressaltamos que, segundo o referido autor, cada cena é configurada por seus componentes: corpo do ator, voz, música, ritmo, espaço, tempo, ação, figurino, maquiagem, objeto, iluminação, texto e contexto. Entretanto, nosso escrito está centrado na reflexão de alguns textos musicais dos quais elegemos como mais pertinentes para a composição estética do Araruna neste escrito. 
Diferentemente dos demais componentes de cena do Araruna, as letras das canções dão um teor mais vivido de nossa tradição, pois elas ampliam nossa visão sobre elementos da cultura e natureza potiguar, quebrando o cunho eurocentrista presente nos figurinos dos brincantes e na maior parte dos passos das danças. Por esse motivo, entendemos que a musicalidade do Araruna faz com que o corpo transborde em lembranças de um tempo passado, permitindo que o humano se mova em direção à dança que há em si, que diz mais que as próprias narrativas desse fenômeno e, ao mesmo tempo, permite relações mais íntimas com a cultura que nos dá identidade regional e talvez um importante sentimento de partilha de sensibilidades para com seus pares. E, de autoria desconhecida, as canções são sonorizadas de maneira encantadora, por meio dos seguintes instrumentos musicais: pandeiro e sanfona.

As canções que expressam a ideia de tradição relacionada a uma prática do corpo, de víeis popular e folclórico, que se referem ao ato de mobilizar o espírito ao cultivo de uma determinada verdade, ancorada às formas simbólicas, à dedicação à beleza imbricada à natureza e ao sagrado (CHAUÍ, 1994). Essa noção está alinhada a estética da dança e de seus movimentos corporais balizados em uma racionalidade que considera a sensibilidade do corpo brincante que dança. Em linhas gerais, Chauí (1994, p.24-25) esclarece que a "cultura popular" se constitui em um conjunto disperso de "práticas, representações e formas de consciência que possui uma lógica própria" de viver no mundo, atuando em um tenso jogo de conformismo, reprodução, recusa e resistência ao erudito.

Nesse sentido, as danças do Araruna apresentam, por um lado, sentimentos de coletividade, identidade, memória e comunhão, mas, por outro lado, segundo Sarlo (2004, p.121) elementos substaciais que "podem expressar facetas terríveis do fundamentalismo, do nacionalismo, do racismo e do sexismo". Em certa medida, essas danças e seus figurinos trazem algumas características ligadas ao mundo patriarcal, ao puritanismo e ao amor heterossexual, remetendo a tempos remotos de uma cultura aristocrática e européia. Porém, através de uma análise mais minunciosa de suas canções, identificamos a existência de um hibridismo, de uma mistura entre o sagrado e o profano, o potiguar e o europeu, que dá outra tonalidade a essa manifestação.

Por isso, essas danças jamais podem ser vistas como fenômenos genuinamente puros ou alheios às influências de outra cultura para além da brasileira ou mesmo distante de nossa contemporaneidade existencial. Segundo Sarlo (2004), há uma utopia etnográfica quando se tem a crença da existência de uma cultura descontaminada, pois todas as culturas passam por momentos de mesclas ou se constituem de modo híbrido. É por esse prisma que o Araruna se estrutura desde sua origem, em 1956, na permanência e existência social, denominado de "Araruna: Sociedade de Danças Antigas e Semi-desaparecidas" na cidade de Natal/RN.

Para os brincantes do Araruna, o ato de dançar para si é um gesto do corpo que dá força a própria vida e, ao mesmo tempo, é uma atitude manter acesa a lembrança do criador do Grupo, Mestre Cornélio, expressando, assim, uma relação poética das simbologias e ligações entre o sagrado e o profano, a cultura e a natureza, entre outras esferas da existência. Os componentes cênicos do Araruna comunicam a cultura européia do século XVIII, trazendo narrativas do mundo aristocrático de Portugual, bem como inspirações poéticas sobre o amor puritano. Das quinze canções do Grupo, as que apresentam características européias são denominadas Valsa, Polca, Xote, Mazurca e Quadrilha. Enquanto que as que têm elementos mais brasileiros são intituladas de Pau Pereiro, Caranguejo, Camaleão, Jararaca, Bode, Besouro e Araruna, pois essas últimas 
revelam parte da geografia potiguar: o agreste, o semiárido, o sertão e o litoral (MONTEIRO, 2007; MARTINS, 2013).

Diante do rico universo de simbologias do Araruna, optamos pela reflexão de cinco canções: Araruna, Besouro, Camaleão, Mulher Rendeira e Mazurca (COSTA, 2008). Cabe salientar que nosso exercício reflexivo não é estorvar o símbolo, mas sim ilustrar uma parte dele, que revele alguns aspectos mais profundos dessas referidas danças, das quais ainda não foram discutidos ou mesmo divulgados em um texto dessa natureza. Há o interesse de que os símbolos possam trazer cenas, recordações e marcas estéticas que nos conduzam a uma viagem em direção ao mundo da tradição norte-rio-grandense.

Para Eliade (1991), os símbolos organizam a existência humana. Sonhos, desejos, nostalgias e devaneios dão forças à vida, nos projetando a um mundo para além da realidade habitual, haja vista que estruturam imagens das quais não poderiam ser expressas por conceitos, por abarcarem inúmeros planos de referências e um rico conjunto de significações. Assim como ocorre em rituais religiosos, nas danças populares também aparecem imagens que invocam a nostalgia de um passado mitificado, além da saudade de um tempo que acabou e o pesar de não viver no tempo evocado pela música; enfim, "o desejo de algo completamente diferente do momento presente, definitivamente inacessível e irremediavelmente perdido" (ELIADE, 1991, p.13).

A palavra Araruna simboliza a morte e ressureição de uma ave. Segundo Chevalier e Cheerbrant (1982, p.687) o pássaro remete ao "canto de criação", também representa as "relações entre o céu e a terra", significando os estados superiores, divinos e lúdicos do ser. Além de ter o sentido simbólico "da amizade dos deuses com os homens". Talvez essa última significação da palavra pássaro tenha ligação com a relação fraterna existente entre Cornélio e Câmara Cascudo, esse último foi o intelectual que sugeriu o nome Araruna ao Grupo. Por isso, percebemos um sentido para além da dança em si, porque entre esses eles e Djalma Maranhão, sempre foi mantido profundos laços de amizade em prol do incentivo à cultura em Natal/RN4.

O pássaro preto simboliza a inteligência, a personalidade do sonhador, de um artista como o mestre Cornélio foi. Sua simplicidade, espontaneidade e suavidade dos gestos encantou muita gente. Assim como um pássaro, ele esvoaçava seus pés de lá para cá, dançando melhor do que quaisquer outros homens. Por isso, se tornou mestre, ensinando as danças e canções que incorporaram sua existência individual e social. Nesse contexto, a música denominada Araruna traz em sua letra a imagem de um pássaro que vem de outro estado brasileiro, viajando, estando em movimento de voo e fuga, através de um exercício de liberdade, própria da condição natural dos seres pertencentes a essa espécie. Eis abaixo a letra integral da canção:

\section{Tenho um pássaro preto, Araruna \\ Que veio lá do Pará, Araruna, \\ Xô, xô, xô, Araruna \\ Não deixe ninguém lhe pegar, Araruna}

Por sua vez, o sentido do Camaleão também está vinculado à geografia da região potiguar, pois esse animal é um lagarto muito comum de arvoredos do sertão nordestino. Devido a sua camuflagem, engana facilmente seus predadores, confundindo-se com a cor da paisagem do seu

\footnotetext{
${ }^{4}$ Consultar Costa (2008) para conhecer os registros sobre essa amizade a favor da cultura potiguar, pois o doador do terreno para a construção da sede própria do Grupo foi o atual prefeito da época: Djalma Maranhão.
} 
entorno (COSTA, 2008, p.88). Esse estudo mostra que essa versão da referida canção também é atribuída a poetas anônimos da cultura popular do estado do Rio Grande do Norte/RN, sendo referenciada como por outros estudos "como dança rural, de vários pares, miudinha como uma chula", como afirmou Aluízio Alves.

Chevalier e Cheerbrant (1982, p.170) afirmam que a palavra Camaleão também simboliza o caminho do céu e da terra, tendo, inclusive, a representação de uma divindade superior, que permite ao Sol entrar em comunhão com os homens. Uma característica que o diferencia é sua "impressionante bipolaridade", "diurna e noturna", que reúne os poderes e os fracassos humanos, porque ele é "um ser sociável, capaz de estabelecer uma relação agradável seja com quem for e, ao mesmo tempo, pode ser hipócrita, não tendo personalidade" confiável. A segunda música traz o Camaleão como um personagem que é adaptável ao ambiente humano, sendo capaz de expressar uma linguagem articulada, de falar com um político, um representante do povo. Por tal proeza, tão poderosa, ele é adjetivado de "nobre".

\title{
Camaleão foi ao Palácio \\ Falar com o presidente (bis) \\ Foi coisa que eu nunca vi \\ Camaleão falar com gente (bis) \\ Ó gente! Ó gente venham ver \\ O nosso nobre Camaleão (bis)
}

Tanto a canção Araruna quanto a canção Camaleão estão ligadas a representação da natureza, do instinto, do conjunto de forças profundas que nos animam, desabrochando outro olhar para essas obras da arte popular. Para Chevalier e Cheerbrant (1982), os animais formam identificações parciais dos homens, porque trazem aspectos, personificações e imagens de pulsões profundas e selvagens, de uma natureza complexa que corresponde a uma parte de nós mesmos, integrada a nossa própria condição humana. Esses autores retomam o pensamento de Leví-Strauss quando citam:

[...] é porque o homem constata ser primitivamente idêntico a todos os seus semelhantes (entre os quais é preciso incluir os animais) que adquirirá a capacidade de distinguir-se tal como os distingue de adotar a diversidade das espécies como apoio conceitual da diversidade social (CHEVALIER; CHEERBRANT, 1982, p.57).

Segundo Costa (2008), a canção denominada Besouro faz referência a uma pessoa considerada "penetra de festas" do Oeste Potiguar, a um "inseto" presente na vegetação norterio-grandense, aos sentidos mais primitivos da existência assim como Araruna e Camaleão; por esse motivo, também exemplifica uma cena de pulsão mais corporal e selvagem dos humanos através de uma "modinha" que remete uma situação de relações sexuais em forma de sátiras, pois os rapazes mais salientes ensaiam carícias e malícias com as moças "ferroadas" por besouros.

\author{
Menina olha o besouro \\ Com seu ferrão afiado \\ Pois ele Ihe ferroando \\ Seu corpo fica inchado \\ Cuidado com o besouro \\ Que ele é macho e vem danado
}


Essa letra mostra um discurso do corpo licencioso (VIEIRA, 2012) construído por características libidinosas em uma sensualidade e sexualidade intrínseca ao corpo feminino e masculino, havendo uma maior evidência da dimensão profana dessa manifestação cultural. Despertando o riso, a erotização e a sensibilidade do corpo no momento de ouvir, olhar, cantar e dançar o Besouro, pois os brincantes engajam sua vida pessoal, sua cultura e suas influências, revelando o modo de ser potiguar e de celebrar a existência que são interiorizados nessa encenação musical.

Parecida com a anterior, a canção intitulada de Mulher Rendeira, nos traz sentidos alheios aos valores religiosos, tendo um cunho mais obsceno, leve e liberto de coerções, focado em uma relação menos sagrada e mais horizontal entre os elementos feminino e masculino, pois eles representam, segundo Chevalier e Cheerbrant (1982), a força dos contrários, a bipolaridade que, em maior ou menor grau, dependendo da interpretação de uma dada cultura, coexistem uma na outra, se complementando.

\title{
Olé mulher rendeira \\ Olé mulher renda \\ Tu me ensina a fazer renda, \\ Que eu te ensino a namorar
}

De acordo com a leitura de Costa $(2008$, p.91), essa versão surgiu em Aroeira, município de Luiz Gomes/RN, referindo-se às aptidões femininas de fazer renda, bem como se configurando em uma forma mais atual e sensual da música, por duas razões, na primeira letra há uma estrutura mais fiel a oralidade potiguar, pois o "me" é pronunciado por "mi", "mulher" por "mulé" e "ensina" por "insina". Essa canção se aproxima do "ritmo do xaxado", estando relacionado ao fenômeno do Cangaço, por tal motivo, o sentido guerrilheiro, de luta é expresso pelo trecho anterior " $\mathrm{Qu}$ ' $\mathrm{eu}$ ti insino a guerriá", que sofre mudança por meio de uma conotação mais sensual pela frase "Que eu te ensino a namorar".

A quinta canção é interpretada com passos da Mazurca, que lembram uma mistura de Polca e Valsa. Segundo Costa (2008, p.90), a letra se refere ao apelido dado a uma velha escrava, de nome Joana, que foi adaptada pelo mestre Cornélio. E quanto a sua coreografia: "o dançarino que dançasse com ela, poderia vendê-la, e com o produto de venda, adquirir o que necessitasse em sua residência".

\author{
Eu sou de Joana \\ Porque Joana é minha, \\ Vou vender Joana, \\ Pra comprar farinha. \\ De ladeira acima, \\ Ou ladeira abaixo, \\ Só vai com Joana, \\ Se for cabra macho.
}

Essa canção é um exemplo nítido de uma obra artística que reforça a assimetria de gênero, pois há uma dominação severa do masculino sobre o feminino, havendo uma visão estereotipada e preconceituosa da mulher. Segundo Alves (2011, p.14), "o preconceito é realmente um aspecto que ronda o universo da dança, pelo fato de rondar concomitantemente o mundo vivido por cada um de nós". Nessa cena, é possível perceber a mulher na condição de um objeto disponível à 
comercialização masculina, nos motivando a superar os modos de exclusão ainda existentes dessa lógica arcaica da cultura a luz do olhar atual sobre as formas de como se dão na sociedade.

Os brincantes, no instante em que dançam, se inserem no contexto da tradição norte-riograndense, expressando e (re)significando determinados sentidos estéticos, educativos e lúdicos da cultura. Segundo Medeiros (2010), esse dançar constitui a memória de gerações, eterniza acontecimentos da vida, envolve a existência, mantendo-se viva e presente, sendo uma fonte de saber. Há nessas danças a possibilidade de acessarmos a uma parte do rico e dinâmico universo da tradição brasileira, nos permitindo compreender a cultura, a arte, a educação e a estética como fenômenos tecidos no corpo.

Todas as narrativas das canções revelam um corpo humano atado ao mundo da cultura e da vida através de uma lógica recursiva, que mistura a prosa à poesia (NÓBREGA, 2010). Sua gestualidade configura um horizonte aberto da percepção sobre o universo estético, em outras palavras, o corpo deixa de ser visto como um objeto inanimado, passado a ser comparado à obra de arte, na visão da fenomenologia de Merleau-Ponty.

O corpo fenomenal age no mundo da cultura, existe no mundo, se movimenta, se comunica, buscando uma aproximação direta com a humanidade, ultrapassando, influenciando e, ao mesmo tempo, indo além de sua condição natural de vida. Sua presença é real, pois amplia seus próprios horizontes de ação, atribuindo uma nova gama de sentidos, conflitando os signos e as convenções usuais a partir da sua linguagem. Logo, o movimento do corpo é, segundo MerleauPonty (1999, p.172), "habitado por uma potência de objetivação, por uma função simbólica, uma função representativa, uma potência de projeção" que ordena a memória do sensível e também fornece brechas para a feitura de outros sentidos da dança e da Educação Física.

As cenas musicais trazem uma permanência da tradição e da atmosfera sensível que se apresenta de maneira dúbia e paradoxal, porque configuram imagens simbólicas que mostram expressões sagradas e profanas, animalidades, sentimentos, preconceitos, entre outras significações humanas que desenham uma estética do corpo fundamentada em valores culturais, revelando uma sabedoria antiga que fecunda nossa imaginação, potencializando a própria existência, bem como alarga os horizontes de sentido para a Educação Física. Isso porque as canções são sublimadas no plano de pensamento por uma potência simbólica que as ultrapassa, mas é sobre a base da visão interpretativa singular que pode se construir outra lógica, uma nova verdade do corpo e da cultura.

Concordamos com Vieira (2012) quando afirma que os folguedos populares brasileiros sofrem transformações ao longo de sua historicidade e, ao mesmo tempo em que apresenta características de licenciosidade, esse corpo não perde sua beleza, seu lirismo por meio do arrebatamento poético, da imaginação, do sonho, do prazer e do riso, quando revelam duplos sentidos em suas músicas. Segundo o referido autor, a estética desse corpo pode ser capaz de incentivar a discussão e a transgressão de verdades instituídas, nos fazendo mais humanos.

É o corpo em sua plenitude que se torna sensível e repleto de música, move-se em direção a estruturação de um logos estético da dança, que permite um fazer artístico que vivencia o passado, fazendo-se presente e instituindo novidades para o porvir da cultura. Logo, essas cenas e simbologias da dança e da cultura dão poder ao corpo de dançar para si, para que o brincante sinta a força da sua própria vida e existência à dança, por meio de uma indivisão de sentidos (NÓBREGA, 2008a). Assim, essa estética da dança se refere aos estados do corpo, suas sensações e afetos, 
através de um exercício criativo de um tempo vivido, no qual somos levados a uma situação subjetiva e mais humana, de comunhão conosco e com os outros que participam do mundo da tradição.

Nóbrega (2010, p.93) afirma que é a partir da experiência sensível com a arte da linguagem que o humano se constitui em seus movimentos e paradoxos do viver. A "sensibilidade estética" amplia e, ao mesmo tempo, sintetiza o modo original de ser, estar e existir no mundo. Desse modo, é necessário considerarmos a "reversibilidade dos sentidos", apontando para outras formas de sensibilidade para além do olhar, considerando o tato, o movimento e a audição para além da objetividade da dança, mas a "dimensão poética da comunicação".

Nesse sentido, a musicalidade do Araruna ampliam os sentidos e as simbologias do Grupo, mostrando outros sentidos que se dão no dançar e vão além do dançar. As narrativas das letras das músicas trazem conotações estéticas ligadas à sexualidade, à natureza e à cultura, desvelando relações entre homem e mulher, homem e animal. Por esse viés, percebemos que tal estética solicita um convite à contemplação de uma beleza peculiar, cuja experiência perceptiva da obra dançante aguça a sensibilidade humana, provocando movimento, prazer e arrebatamento corporal, no qual gera uma dinâmica interpretativa das diversas expressões culturais, infinitas simbologias das danças. O Grupo Araruna pode trazer uma nova lógica de estar junto e de compartilhar emoções, assim como afirma Porpino (2006) quando escreve que dançar pode permitir o acontecimento do abraço afetivo, que rejunta fragmentos e abre novos horizontes para uma vida mais significativa, não negando nem se limitando a própria realidade contraditória do viver. Por essa razão, a estética do corpo no Araruna também desvela características da cultura que nos motivam a reestruturar os sentidos da tradição popular em um movimento de ressignificação, debate e crítica das simbologias das canções e dos demais componentes cênicos do Grupo para o alargamento da estética, dos símbolos, do corpo e das ideias da Educação Física.

\section{UMA ESTÉTICA DO CORPO PARA A EDUCAÇÃO FÍSICA}

A estética do corpo é desenhada a partir da metáfora das asas de um pássaro denominado Araruna. Essa palavra é o sentido central de nossas ideias para o exercício de alçar voos de nossos pensamentos sobre cultura, tradição, dança e da própria Educação Física. Nossa viagem interpretativa se dá através das canções, palavras, letras e simbologias contidas na musicalidade do Grupo, que se configura como emblemático exemplar da cultura e tradição norte-riograndense, na qual também se condensa a determinados fios de sentido da cultura europeia.

A musicalidade das danças configura uma nova compreensão de estética e de corpo que se pauta em um exercício vibrantemente simbólico de alçar novos voos da imaginação, ampliando o olhar da Educação Física sobre a tradição, o corpo, a cultura e a dança em si. Em outras palavras, percebemos que a estética dos corpos brincantes do Araruna trazem outros sentidos que enriquecem as reflexões e também o próprio campo de conhecimento da Educação Física, superando raízes racionalistas e dicotômicas que ainda hoje se encontram arraigadas no pensamento científico e pedagógico de grande parte da produção de saberes dessa área de conhecimento.

A leitura das canções traz algumas perspectivas estéticas para um exercício de repensar os conceitos sexualidade e natureza, além das tensões entre masculino e feminino, sagrado e 
profano, popular e erudito, haja vista que elas também estão em nós, configurando uma ampliação das noções de corpo e cultura presente nos símbolos do Araruna. Fundamentada na fenomenologia, essa reflexão trouxe a compreensão de que investigar as dança da tradição é uma tarefa de grande valia, haja vista que há o movimento em direção a novos horizontes de percepção sobre a estética, a memória e a própria Educação Física para além das verdades já produzidas.

O estudo do simbolismo das danças do Araruna permitiu o exercício de uma composição estética do corpo na cultura potiguar que desvelou novas relações entre corpo, cultura, dança, natureza, ludicidade e sexualidade. Tais dimensões constituem forças profundas que integram, educam, animam e potencializam a existência humana. Entende-se que essas simbologias podem ampliar o olhar estético e espaço de reflexão da dança e da Educação Física, pois permite reconhecer os diferentes corpos e culturas, valorizando a riqueza das danças, saberes, símbolos, lendas, crenças, histórias, identidades, coletividades e diversidades humanas.

A reflexão sobre as cenas musicais e as simbologias da dança possibilita um determinado poder ao corpo para criar, imaginar, dançar, lembrar, esquecer e se impregnar de valores da tradição, necessitando de outros referenciais poéticos que deem abertura para outra reflexão sobre a beleza do gesto, da música e a própria existência do Grupo Araruna na contemporaneidade. Atrelada a essa visão, temos o desafio de alargar a atmosfera estética do corpo e da cultura através de outras estratégias metodológicas de investigação da Educação Física que possibilitem maior tatilidade e aproximação com o Grupo, dando mais volume ao corpo de ideias em busca de novidades sobre o objeto de estudo.

O fenômeno estético Araruna mostra que nossa cultura potencializa a imaginação corporal pela sua própria riqueza simbólica das danças, que nos motivam a continuar o estudo para a uma leitura estética do corpo não apenas por meio dos textos musicais, mas também dos outros componentes de cena que compõem o Grupo, tais como: os brincantes, a voz, o ritmo, o espaço, o tempo, a ação, o figurino, a maquiagem, a iluminação, entre outros. Logo, cabe a Educação Física elaborar argumentos estéticos que se balizem na reversibilidade dos sentidos de Merleau-Ponty, os quais colaborem na superação de fraturas epistemológicas, que reduzem o entendimento estético do corpo que dança, vibra e encanta a tradição potiguar. Por fim, perspectivamos que esse escrito mobilizem outras reflexões que se ancorem na beleza das imagens, na riqueza das narrativas e nas danças do Araruna para além desse folguedo, estando em sintonia com uma visão mais contemporânea da tradição.

\section{REFERÊNCIAS}

1. ALVES, T. A. Módulo didático 1: Dança e pluralidade cultural. Natal/RN: UFRN, 2011.

2. CHAUÍ, M. Conformismo e resistência. São Paulo: Brasiliense, 1994.

3. CHEVALIER, J.; CHEERBRANT, A. Dicionário dos símbolos: mitos, sonhos, costumes, gestos, formas, figuras, cores, números. Tradução V. C. Silva. 20 ed. Rio de Janeiro: José Olympio, 1982.

4. COSTA, G. Araruna: sociedade de danças antigas e semi-desaparecidas - orgulho e patrimônio cultural do RN. Natal/RN: SESC, 2008.

5. ELIADE, M. Imagens e símbolos: ensaio sobre o simbolismo mágico-religioso. Tradução S. C. Tamerl. São Paulo: Martins Fontes, 1991. 
6. MARTINS, J. S. Araruna: das naturezas histórica, material e simbólica à espacialidade da cultura. Revista GEOTemas, n.3, v.1, p. 211-225. Disponível em: http://periodicos.uern.br/index.php/geotemas/article/view/602/370. Acessado em: 20 ago. 2013.

7. MEDEIROS, R. M. N. Uma educação tecida no corpo. São Paulo: Annablume, 2010.

8. MERLEAU-PONTY, M. O olho e o espírito. São Paulo: Cosac \& Naify, 2004.

9. ㄴ. Fenomenologia da percepção. Tradução C. A. R. Moura. São Paulo: Martins Fontes, 1999.

10. _ O visível e o invisível. Tradução: J. A. Gianotti \& A. M. d’Oliveira. São Paulo: Perspectiva, 1971.

11. MONTEIRO, N. A. Um olhar sobre o Araruna: perspectivas para a dança na Educação Física. Natal/RN, 2007. Monografia de graduação - Departamento de Educação Física - Universidade Federal do Rio Grande do Norte. Natal/RN, 2007.

12. NÓBREGA, T. P. Uma fenomenologia do corpo. São Paulo: livraria da física, 2010.

13. NÓBREGA, T. P. A dança como poética do corpo e da vida. Natal/RN, 2008a. Disponível em: http://petrucia-blogcorpo.blogspot.com.br/?view=flipcard. Acesso em 02 mai. 2014.

14. NÓBREGA, T. P. Merleau-Ponty: o corpo como obra de arte e a inexatidão da verdade. In: Cronos - Revista do Programa de Pós-Graduação em Ciências Sociais da UFRN, v.9, n.2, p.393403, jul./dez., 2008b.

15. PAVIS, P. A análise dos espetáculos: teatro, mímica, dança, dança-teatro, cinema. Tradução S. S. Coelho. São Paulo: Perspectiva, 2003.

16. PORPINO, K. O. Dança é educação: interfaces entre corporeidade e estética. Natal/RN: EDUFRN, 2006.

17. SARLO, B. Culturas populares, velhas e novas. In: B. SARLO (Org.). Cenas da vida pós-moderna: intelectuais, arte e vídeo cultura na Argentina. Tradução S. Alcides. 3 ed. Rio de Janeiro: UFRJ, 2004.

18. VIEIRA, M. S. Pastoril: uma educação celebrada no corpo e no riso. Jundiaí: Paco editorial: 2012. 